\title{
Making Canada Home: Snapshots of Syrian and Iraqi Newcomer Cultural Production in the Waterloo Region, 2016-2019
}

\author{
ANNE VERMEYDEN AND EID MOHAMED
}

\section{Abstract}

Since the beginning of the Syrian Crisis in 2011, millions of refugees from Syria and Iraq have been displaced. Over 25,00o Syrian newcomers settled in Canada between 2015 and 2016. ${ }^{1}$ The Region of Waterloo, home to a population of approximately 535,000 by 2016, ${ }^{2}$ was where about 2,000 of these newcomers settled. ${ }^{3}$ This article argues that these newcomers have used arts and culture to navigate the difficulties of settlement and acculturation. Evidence from newspaper articles, interviews, and participant observation indicates that refugees from Syria and Iraq in this region have utilized dance and theatre to develop community that retains cultural connections and identity linked with Syria and the greater Levantine region. Professional and community arts initiatives spearheaded by refugees showcase how culture and identity are caught up in continuous circulations of culture that are geographically situated in the Canadian context. For Syrian and Iraqi refugees in the Waterloo Region, acculturation, nostalgia, and assimilation are complex and powerful sites of community.

\section{Résumé}

Depuis le début de la crise syrienne en 2011, des millions de réfugiés de Syrie et d'Irak ont été déplacés. Plus de 25 ooo nouveaux arrivants syriens se sont installés au Canada entre 2015 et 2016. Environ 2 ooo de ces réfugiés se sont installés dans la région de Waterloo, qui abritait une population approximative de 535154 personnes en 2016. Cet article soutient que ces nouveaux arrivants ont utilisé les arts et la culture afin de faire face aux processus difficiles d'installation et d'acculturation. Des données tirées d'articles de journaux, d'entrevues et d'observations participantes indiquent que les réfugiés syriens et irakiens ont fait usage de la danse et du théâtre pour développer une communauté qui conserve des liens culturels et une identité en rapport avec la Syrie et la grande région du Levant. Des initiatives professionnelles aussi bien que communautaires menées par des réfugiés démontrent comment la culture et l'identité sont impliquées dans de constantes circulations culturelles situées géographiquement dans le contexte canadien. Pour les réfugiés syriens et irakiens dans la région de Waterloo,
( $)$ Anne Vermeyden and Eid Mohamed, 2020. This open-access work is licensed under a Creative Commons Attribution-NonCommercial 4.0 International Licence, which permits use, reproduction, and distribution in any medium for non-commercial purposes, provided the original authorship is credited and the original publication in Refuge: Canada's Journal on Refugees is cited.
Cette œuvre en libre accès fait l'objet d'une licence Creative Commons Attribution-NonCommercial 4.0 International License, laquelle autorise l'utilisation, la reproduction et la distribution de l'œuvre sur tout support à des fins non commerciales, pourvu que l'auteur ou les auteurs originaux soient mentionnés et que la publication originale dans Refuge: revue canadienne sur les réfugiés soit citée. 
les processus d'acculturation, la nostalgie et l'assimilation sont des sites complexes et puissants de communauté.

\section{Introduction}

7 efore the 2011 uprising, Syria had turned into a police B state, and the security services had become the backbone of the system. This gave the regime extensive powers to interfere in the everyday details of citizens' lives. The country was in a perpetual state of emergency, which provided the legal basis for the absence of any rule of law. For decades, the practices of the security services constituted a direct violation of the dignity of Syrians, through the policies of arrest, torture, intimidation, repression, and the suppression of freedom of expression. After the success of both the Egyptian and Tunisian revolutions in removing Presidents Hosni Mubarak and Zine El Abidine Ben Ali from power, Syrians were beginning to feel that a change in the structure of the totalitarian Baathist regime that had governed Syria since 1963 was possible. This is what motivated the revolutionary youth to embark upon a struggle that aimed to create a different political, social, and economic reality, one based on freedom, democracy, equal opportunity, and the rule of law, to replace the reality established by the regime, which was based on tyranny, repression, and the monopoly of wealth.

According to the Pew Research Center, as of 2017, nearly 13 million Syrians were displaced globally. By the end of that year, 54,00o Syrian refugees had settled in Canada, and during 2019, 55 per cent of refugees settled in Canada came from Syria or Iraq. 4 This movement has altered the ethnic and socio-cultural makeup of Arabic-speaking communities in many parts of Canada, and it has meant changes in Arabic cultural ${ }^{5}$ production across the country. Not surprisingly, there has been an increase in cultural production by both professional and community arts groups within Canadian Arabic-speaking communities addressing themes of displacement. As a case study, this article focuses on refugee cultural production in the Kitchener-Waterloo Region of Ontario between late 2017 and early 2018. Newspaper articles, interviews with displaced Syrians, and participant observation all indicate that Arabic theatrical and dance cultural production in the Waterloo Region is being used to navigate settlement acculturation and to resist narratives of refugee helplessness. In addition, community theatrical and dance productions strengthened community in ways that reach across borders.

\section{Methodology Note}

This article is based on three sets of primary source evidence. The first is a set of interviews with twenty-eight Syrian and Iraqi refugees who settled in the Kitchener-Waterloo Region after the Syrian crisis began. About ten of these participants were involved in the artistic productions listed below. Almost all the interviewees had received services or support in some way from local community non-profits that support refugees like Levant, Shamrose for Syrian Culture, and the K-W Multicultural Centre. ${ }^{6}$ Furthermore, all participants indicated that they had taken part in Syrian or Arabic cultural events and/or activities upon arriving in Canada. The second source of data is documentary evidence from newspapers and ephemera detailing refugee professional and community theatre and dance productions in the region between 2016 and 2019. The key productions the authors attended, collected data at, and/or participated in included Rajaeen $\mathrm{Ya}$ Hawa (2019), Sahel el Ward (2018), The Mug (2017), Sultan Basha (2017), and Adrenaline (2017), along with over fifty different dabke (Levantine line dance) presentations of the Levant Dabke Troupe. Finally, as both authors are embedded in Arabic-speaking communities in the region, data were collected through participant observation.

In the case of this project, language, culture, and time filtered interviewees' creative acts of recollection.7 Interviewers used Modern Standard Arabic, various Syrian dialects, and/or English to interview. In some instances, participants acted as translators for one another in the context of group-interviews/focus groups with families and close friends. There was significant language fluidity in many of these interviews (some started in English and ended in Arabic; others began in Arabic, switched to English, and ended in Kurdish). This reflected participants' complex linguistic identities and their linguistic readjustment upon arrival to Canada. The interviews were semi-structured and focused primarily on exploring the transition from the Middle East to Canada, and participation in cultural production after arrival in Canada. Interviews were done in a way that prized conversation and interaction, and thus did not follow a codified set of questions. The content of these interviews is thus a product not only of the newcomers' memories, but also of their cultural context, genders, ages, appearances, and backgrounds.

Documentary evidence in the form of newspaper articles, blog posts, and ephemera further grounded the study. To centre refugee voices and agency, the research team was cognizant of positionalities and the power imbalances inherent in academic research practices. The team recognized interviewees as equal partners in knowledge creation with the goal of mitigating power imbalance in the research relationship. ${ }^{8}$ For example, interviewees who wished to have their intellectual input recognized by name are directly cited and credited in this article. ${ }^{9}$ Participants who preferred anonymity have also had their wishes respected, and their contributions have 
remained anonymous. This choice, to be named or to remain obscured, empowers the narrator in the interview. ${ }^{10}$

Participant observation was chosen so that the researchers could build relationships during the research period. Being connected to those participating in the research through relationships allowed for opportunities to support newcomer initiatives and arts objectives. It also allowed for a level of sensitivity and sharing that is not always present in more formalized interactions. Two contributors to this paper, Anne Vermeyden and Helen Ala Rashi, have been extensively involved with the cultural production of the Shamrose and Levant Refugee agencies. Both researchers have been dedicated to connecting with community and offering assistance to participants when possible. One hurdle to this research was the potential for accessing traumatic stories, while offering no support or recourse. Through developing relationships and continuing to volunteer with participants, the researchers aimed to mitigate this possibility. Anne Vermeyden also joined the Levant dabke group, allowing her to get an insider perspective on the group's dance activities, including dabke productions, fundraisers, and the plays Rajaeen ya Hawa and Sahel el Ward. Vermeyden also participated in dance activities through these groups, and furthermore is a community leader because of her activism for refugee causes. Throughout the study, both Ala Rashi and Vermeyden dedicated considerable resources to aid participants by helping advocate for participants' needs (i.e., in accessing health care or navigating government structures) and by offering translation services when needed. Although the power imbalance between researchers and participants cannot be removed entirely, it was hoped that it was diminished through these methodological considerations. This style of research may be criticized, as it limits supposed objectivity; however, any research relationship faces this challenge. This clear disclosure of research and relationship serves to ground understanding of the conclusions reached.

\section{The Syrian Crisis}

When demonstrations erupted against the regime of Bashar Al-Assad in 2011, the response of repressive violence and the resultant protracted armed conflict in Syria and Iraq displaced millions. ${ }^{11}$ This extended conflict quickly involved numerous regional powers, including Iran and Russia, who offered support to Assad's regime (Russia even had military forces on the ground in Syria as of 2015). ${ }^{12}$ Turkey, Saudi Arabia, Qatar, Jordan, the United States, France, and the United Kingdom have, on the other hand, offered varying degrees of assistance to a variety of opposition Sunni groups. ${ }^{13}$ Little progress has been made in resolving this conflict: there are reports of continued use of chemical weapons and barrel bombs. ${ }^{14}$ Peace talks also continue to stall. Russia and China consistently block any decisive UN action to abate the disaster. ${ }^{15}$ As a result of this conflict, as of 2016 the Un estimates that approximately six million Syrians were internally displaced, while five million were forced to flee the country as refugees. ${ }^{16}$ The conflict and the growth of the Islamic State in Iraq and Syria (ISIs) has had a significant negative effect on both Syria and neighbouring Iraq.

The emergency shattered the social structure and fabric of Syria and resulted in massive international shifts of the diverse Syrian and Iraqi populations. Syria itself was multiethnic and home to numerous faiths because it had itself long been a home for refugees; Syria and Iraq were home to a sizable Kurdish minority (and part of Kurdistan), as well as minorities of Tartars, Circassians, Armenians, Assyrians, Eritreans, Ethiopians, and Palestinians. ${ }^{17}$ Before the emergency, Sunni Muslims comprised 65 per cent of Syria's population, while 35 per cent of the remaining population was made up of Christians of various denominations, along with Alawites, Druze, and Ismailis. Refugees of the crisis have come from all of these groups. Many have moved to other states within the Middle East and some to Europe, but thousands have also managed to escape to Canada.

\section{Canadian Socio-political Context}

As the world sees unprecedented displacement due to armed conflicts, controlling who enters the country has become a major issue in Canadian political discourse. Canadian and American conservatives have implied links between refugees and international terrorism, have used language to describe Syrians as a horde or wave, and have dehumanized and othered the group to please xenophobic populist movements. ${ }^{18}$ Canada's Conservative government under Stephan Harper was purposefully restrictive in its policies towards Syrian refugees, and in fact limited refugee acceptance early on in the crisis, barely reaching 1,000 accepted to Canada by 2013. The refugees the Harper government did accept were unfairly prioritized on the basis of business backgrounds and religion. ${ }^{19}$ Gaining refuge in Canada is not easy, as Canada, geographically far from Syria, has been able to strictly control refugee entry to the country.

The sharp increase in Canada's settlement of displaced Syrians during 2016 was not inevitable. It was the result of public objection to restrictive refugee acceptance policies during divisive national elections. ${ }^{20}$ During the October 2015 federal election, the Liberal party reiterated its earlier April 2015 call for 25,000 refugees to be admitted to Canada. This election promise to bring 25,000 displaced Syrians to Canada resonated with many who had become concerned about the humanitarian crisis. This campaign promise contributed in part to Justin Trudeau's election, as it appealed to many Canadians who were increasingly sympathetic with 
displaced Syrians. ${ }^{21}$ The new government completed its promised resettlement of 25,000 refugees between November 2015 and February 29, 2016. ${ }^{22}$ The American presidential election that followed in 2016 also helped shape Canada's 2016-19 refugee response. Protecting and supporting Syrian refugees became a marker of supposed Canadian superior morality. Canadians embraced narratives of Syrian support, in part as a way to distance their nation from Trump's America. ${ }^{23}$

\section{Making Canada Home}

It was in this context that refugees who were interviewed for this case study came to Waterloo Region between 2013 and 2017. While those interviewed agreed that settling in Canada was far from easy, many expressed that the region was very welcoming in comparison to many other nations they had passed through on the way to Canada. Many shared that they did not feel welcomed and even faced harassment and assault in countries such as Lebanon and Turkey. Interviewees reported experiences of violence or humiliation that they believed they had experienced because of their ethnicities. One man interviewed was stabbed in an altercation in Lebanon, and another was beaten at the Turkish border. The experience of finally being permitted to settle in Canada was a relief for many. One participant stated that Canadian society's way of welcoming them resembles a mother giving a hug to her child: "Their respect is enough, that they took us in. Exactly like a mum who takes in the kids. We felt like the nation takes us in like a mum who hugs her kids, and that was more than enough for us. Even the neighbours took us in." 24

The majority of participants reported that on the whole they did not feel discriminated against because of their race, ethnicity, or religion in Canada. There is a chance that the growing diversity of the region allowed for such tolerance; as of 2018, 22.6 per cent of Waterloo's Region are immigrants, and one in five residents are members of visible minority groups. ${ }^{25}$ Or perhaps there was a sense of welcome and respect because Waterloo Region is home to numerous community programs that help ease newcomer transitions and settlement. ${ }^{26}$ Interviews consistently indicated that many Canadians were helpful and kind. Refugees interviewed reported that they received help from Canadians in their settlement and integration: "When we first moved here, everyone was welcoming. They would smile in our face. I've been living in Canada for almost one year and a half, and no one has ever given me an uncomfortable look. I don't know how to describe this to you. Wherever I go I find kindness." 27 Safety, freedom, and equality are some of the positive traits that participants attributed to Canada. Female refugees especially felt themselves freer and more equal to men in Canada.
They also viewed Canada as a place of safety: "Women are so much safer here. It's incredible. I mean I don't fear for my daughter to walk on the sidewalk, or for someone to come and harm my son. Even the little ones, if they're playing by the door outside, it's safe. I really appreciate these things." 28

However, these positive reports should not be taken at face value. There are a variety of reasons people may have chosen not to reveal these less welcoming experiences. For instance, perhaps some participants chose to keep problematic experiences to themselves in order to save face for their Canadian interviewers. While most interviewees described life in Canada as generally positive, many also discussed experiences of micro-aggressions and societally pervasive racist and orientalist attitudes. ${ }^{29}$ For instance, an interviewee explained how her son, in grade nine, had another student exclaim in front of the class, "You people are terrorists!"30 Women who wear the hijab who were interviewed also related that they were often automatically assumed to be foreign to Canada by white Canadians.

For example, a participant expressed that her daughter faced discrimination because of her hijab: "My kid's in high school now, my daughter. She wears the hijab. She also faced a lot of difficulties, and until now she's facing them. It's been a year for us here. Maybe there's one girl in her school that talks to her [and became close friends], and she's originally Turkish, she's not Canadian, you see. Canadians, I don't know, they hang out together, and for her, since she wears a hijab, this hijab is causing her a big problem." ${ }^{1}$

Reem Hijali, a young Syrian woman, also related experiencing unwelcome comments at school on account of her hijab: "Sometimes I used to go to the washroom and trying to do my hair under the hijab. And they're like 'Is this the golden hair that you hide?' You know? Like 'Hey-y-y Rapunzel, is this the hair that you can't let anyone see or touch?"32

Newcomers are navigating a Canadian context that is underpinned by stubborn cultural prejudices. Newcomers have had to navigate the attitudes of Canadian citizens and media outlets that participate in silencing and othering them. While the public discourse of "Canadian values" and the "moral imperative" to help refugees in Canada may be commendable, it centres supposed Canadian morality at the expense of Syrian voices. ${ }^{33} \mathrm{~A}$ working paper out of the Ryerson Centre for Immigration and Settlement Program analyzed hundreds of print and video stories from Canada's major news outlets between 2015 and 2016, and it concluded that Canadian saviour-narratives dominated the news, while newcomers were homogenized as passively needy. Furthermore, if refugees were given voice at all in media reports, that voice was typically given to men. ${ }^{34}$ Acts of racism were typically dismissed in papers and news reports as simply unCanadian behaviour. The reality of racism and xenophobia 
within Canada and abuses against refugees were ignored in favour of heart-warming stories. The study found that feel-good narratives about good-hearted Canadians helping newcomers dominated media coverage, and it concluded that generally Canadian media ignored the experiences and feelings of the refugees themselves. ${ }^{35}$ Newcomer cultural production has been a counter-measure to this hostile environment and the limiting representations of media.

\section{Cultural Production in the Canadian Context}

\section{Syrian and Iraqi Newcomer Voices in Theatre}

Through theatre, refugee and newcomer Arab artists in the region have addressed problematic stereotypical media and academic narratives that focus on, or even exploit, refugee experiences. Amir Al-Azraki, an Iraqi newcomer, Renison College professor, and playwright, in his recent production The Mug (2017), powerfully criticized academic consumption and use of refugee trauma narratives. ${ }^{36} \mathrm{Al}$-Azraki organized an event entitled "Arab Culture in Diaspora" on November 23, 2017, at the University of Waterloo. The show featured the work of Arab-Canadian artists, including that of refugees from Syria, Jordan, and Iraq. The goal of the evening was to present "Arab culture and identity in a Canadian context." 37 Al-Azraki argued that diaspora "is a shared human experience" and helped his audience engage with transnational Arab arts in the Waterloo Region by championing newcomer artists. ${ }^{38}$ At this event The Mug was performed by an IraqiCanadian actor, also a refugee to Canada, Addil Abbas Hussain. Hussain performed the monologue piece and embodied the darker elements of refugee experience. He railed against those who took pleasure in pitying him, or who profited from his story of suffering. In the monologue he mocked "Canadian saviours." He had vitriol for academics who preyed upon his story to gain tenure or other professional advancement. Al-Azraki and Abbas Hussain made a theatrical piece that validated refugee frustration and anger at their unfair treatment. These newcomer artists offered up a space to challenge the "stereotypical grateful refugee success story." They used theatre to present and validate frustrating, even painful narratives that they had faced during acculturation.

Pressure to be grateful, even as Canadians continue to spotlight traumatizing refugee life-narratives, is something newcomers have found space to resist, in part through cultural production. One interviewee took time to describe his frustration with being constantly understood only as a refugee in Canada. This pigeonholing of his identity affected his art and his life. In Canada many people pressured him to feel grateful for his experience, saying, "You are in Canada. So you have to feel-" But he responded, "I don't have to feel anything." 39 In artistic spaces these complex feelings were shared within the newcomer community and with wider Canadian audiences.

For instance, the plays Adrenaline and Sultan Basha were part of a Syrian double bill at Kitchener-Waterloo's Registry Theatre on February 16, 2017.40 Ahmad Miree, a displaced Syrian playwright and actor, wrote Adrenaline not long after arriving in Canada. ${ }^{41}$ The piece, written and performed in his Aleppo dialect of Arabic (with English subtitles), explored the psychological effect of war and the loss of family on one man through the lens of his first New Year's Eve celebration in Canada. ${ }^{2}$ The show was emotionally powerful and captured not only longing, loss, and trauma but also stubborn and hopeful resilience. He chose to present the play to Canadian audiences in Arabic with subtitles, so that there could be a Syrian voice in Canada speaking loudly and with dignity. Through organizations like the YMCA and Reception House, refugees were given free tickets to the performance and were encouraged to invite Canadian friends and acquaintances to the show. 43 After the play's premiere, Miree shared that as a playwright and actor, his writing, directing, and acting skills allowed him to voice emotions and experiences in a way that could draw both Canadian viewers into the Syrian refugee experience. After the performance, Miree mentioned that his use of Arabic as the medium for the play was a proclamation of Syrian resilience and a way to connect and circulate art back to Syria, even if it was presented in Canada.

The second part of this double bill, Nada Homsi's potent historical piece Sultan Basha, presented a female-centred perspective on the events that sparked Syria's 1925 revolution against the French. Homsi's work shared a story central to Syrian heritage and identity with the mixed Syrian-Canadian audience at the opening of the play. Homsi presented a very nationalist rendition of Sultan Basha. She critiqued colonialism in Syria's past in her monologue, but the work was also a critique of both domestic Canadian and current neo-imperial colonial activity in the Middle East. Homsi, as an immigrant who had come to Canada long before the 2011 crisis, was in a position to share a story centred on historical Syrian identity and Syrian resistance to colonial oppression. She could engage in a deep nostalgia as a playwright who had found her place in Canada-as an artistic associate at Multicultural Theatre Space (мт Space-a Kitchener theatre company), and a pioneering Arab artist. ${ }^{44}$ Her play offered Syrian refugee viewers a foundation for their own nostalgia-for a Syria of the past, strong and united against colonizing forces. For a Syria where women's actions were central to political change for the better.

\section{Community Dance and Theatre Groups}

The Levant Dabke Troupe, made up in large part of recent newcomers from Syria, celebrates Levantine dance cultures, 
and its performances help construct group identity while dismantling stereotypical perceptions of a Middle East defined by division and warfare. This community dance troupe is based in Ontario and has presented choreography and workshops at multicultural festivals and refugee fundraiser events across the province since its founding in 2014. Created in response to the growing refugee Syrian community in the region, the group's work is affected by decisions to stand up against stereotypical ideas about refugee identity. The troupe comprises Arab immigrants from a variety of backgrounds, a handful of Canadians from non-Arab backgrounds, and both Kurdish and Arab newcomer displaced Syrians.

The curation of the group's multicultural presentations has been a negotiation of self-representation. For instance, the group makes a point of including Arab and Kurdish performances together to stand against ethnically divided identity politics. The group has worked to centre a variety of cultural expressions from the Levant. Recent refugees from communities in Syria, both Arab and Kurdish, have contributed to choreography development since 2016. The group's most recent choreographic decisions present Syria, Lebanon, and Palestine as multi-ethnic and interconnected (as the group mainly comprises members from all these regions). Despite geopolitical tension, this group has decided to utilize national dance to educate Canadian audiences, and to encourage inter-Arab community development within Canada. It purposefully includes mixed-gender shows and allows flexibility in roles to stand against stereotypes about Middle Eastern conservatism and gendered dance norms. The troupe is also intimately connected with the Levant organization, whose primary mission is refugee assistance and settlement, with a specific focus on support for women and youth. Here arts and culture intertwine with community activism. Members and choreographers of this community dance group are cognizant of the oppressive structures they are operating within - and are not afraid to use dance to challenge them.

In this cultural community group, dance and theatre are used to create tradition and identity in Canada. For example, Levant sponsored the production of the community theatre pieces Sahel El Ward [Meadow of roses] in 2018 and Rajaeen Ya Hawa (Coming home) in 2019. These Arabic community theatre musicals were presented at the University of Waterloo and showcased Arab and Kurdish dancing, singing, and a traditional wedding ceremony from Syria, Lebanon, Jordan, and Palestine. The theatrical group responsible for the production of these shows included recent Arab and Kurdish refugees; the playwright and choreographers were all immigrants or refugees from the Levant region. These shows blended contemporary and traditional wedding practices from across the Middle East and Levant.
Rajaeen Ya Hawa centred on a transnational Syrian narrative because it focused on a comedic long-distance love story where the protagonist returns home to Syria to find his love after spending ten years working in Argentina. Rajaeen $\mathrm{Ya}$ Hawa played with transnational elements of Argentinian, Syrian, and wider Middle Eastern culture in a Canadian context. This was especially evident in the dabke fusion performance done to the song "Talat Daqat" where the performers mixed Spanish costuming elements with Levantine garb to indicate cultural fusion and circulation. In the play, when the protagonist returns from his time in Argentina, he throws Spanish phrases into his Arabic and passes around yerba maté (a popular hot drink in Argentina) to his neighbours and friends.

In constructing cultural expression tied with Syrian identity in Canada, the individuals involved in this community play were forging intercultural linkages. Community plays and dabke performances take on significant meaning. When asked in an interview, "How do you feel when you do dabke?" an interviewee responded, "I feel I'm contacting to my culture. I'm, yes, I'm bringing something with me [to Canada] which is, my grounded. My great-, great-, great-grandparents were doing it and I'm continue ... and so it's part of me. And I feel all the feelings ... I'm bring my culture with me." 45

The performance of dabke with the group was not just an ephemeral experience of movement. It was a physical manifestation of culture and connection to heritage; it was something of Syria he could bring with him to Canada without a suitcase. Even though this participant is not a professional dancer, he participated in sharing and establishing cultural roots here through his performance in the play.

Displaced Syrians have worked to develop a sense of community upon arrival to Canada, and they have used dance, theatre, and other community arts sites to this end-but still, isolation and dislocation remain challenges. Whether they came alone or with family, almost all newcomers interviewed in this project mentioned experiences of loneliness in their transitions to Canada. "I'm living my life, and then when I came here I was like, 'Shoot, I'm scared of being lonely.' And that's exactly what happened. I had no friends." 46 Loneliness, because of either being away from family or not having close friends in Canada, is one of the most reported difficulties they have encountered. Many interviewees complained about homesickness: "I feel so distant from my family. It's not like Europe [where] you can take five-hour flight and get to my family. But from Canada it's very far. Sometimes I'd get sick, and there's no one to help me. This has affected my psycholog$\mathrm{ical} /$ mental health a lot. I got so tired, I went to the doctor. She said my mental health was bad. Even when I go to school, I'm disoriented, I can't focus very well. Even at work, I couldn't focus a lot. Where does my mind wander off?" 47 
Others spoke of not being able to make Canadian friends: "I had so many friends back home.... I used to go to parties every now and then, I'm living my life. And then when I came here, I was like I'm scared of being lonely. And that's exactly what happened." 48

There was also psychological stress that specifically accompanied the reality of being across an ocean from Syria and the Middle East. The large time difference for refugees strained easy communication with those back home. While in Europe, refugees face only a three- or four-hour time difference with Syria, while in Canada, the eight-hour difference is challenging. 49 As a result of the trauma of transAtlantic resettlement, and loneliness in becoming culturally dislocated, newcomers participate in the labour of building new communities and engage in reimagined cultural practices in Canada. For instance, government-assisted refugees in Kitchener were housed together for several months in a Howard Johnson Hotel in 2016 upon their arrival. In this trying experience, newcomers forged lasting relationships with each other. In these social networks, newcomers can participate in social and cultural activities that connect them to both Canada and their homeland. Weddings, parties, and other celebrations attended by primarily Syrians, where Syrian food, music, dance, and cultural norms were practised, were a form of cultural production that mitigated loneliness and strengthened social cohesion here in Canada.

Newcomer cultural production has also affected social cohesion with inter-newcomer and Canadian social networks. Many newcomers took it upon themselves to seek out relationships and interactions with more established Canadians through local cultural programming like English partnership programs through Kitchener's Reception House, the YMCA, and the Working Centre's English Language Café. 50 English partnerships often served as the jumping-off point for friendships. Partners would invite each other to meals or holiday celebrations. The partnerships, however, are uneven because the native English-speaker maintains an aspect of power in the relationship. These bridging platforms have been used as access points for newcomers to share cultural production with Canadians. Within these relationships, Syrians challenge stereotypes. Newcomers who enter programs to learn language engage in uneven sharing, where AngloCanadian norms are prized and normalized, and Syrian cultural production, while respected, is still othered. They are participating in acculturation. Syrian cultural production is shared outside of newcomer communities, but the power dynamic is not balanced.

\section{Cultural Production, Assimilation, and Acculturation}

Many participants in this research project revealed that even though they try to embrace Canadian customs on the surface, they still feel their home cultures breathing inside of them. Of course, they did not choose to leave their home cultures. Displaced newcomers are forced to "make conscious and unconscious decisions about what to include and exclude" in their performance of cultural belonging. ${ }^{51}$ Refugees navigate acculturation, nostalgia, and assimilation forces as they articulate identity and engage in cultural production within Canada.

Assimilation was considered a threat by many of the newcomers involved in the community arts projects, but it was also considered problematic by those who were not. The majority interviewed strongly believe that they have to maintain their Syrian identity while integrating into Canadian society. Arabic language competency was perceived as an important part of identity. One participant stated that she was worried about her children's retention of language, faith, and general culture. She described fears of a complete loss of Syrian identity:

To preserve the faith of your kids in such an open and diverse society, it can be very difficult. There has to be something from our own environment to help us. This is very important, when we know what is needed, so that in one year or two, they will change into different people. As much as you try at home, you won't be able to help them, there isn't anything. Even teaching Arabic on Sundays, this is good, but this is very little. The kids forget what they learn in three hours. My daughter is five years old, she speaks English threequarters of the time. At school, she speaks English, TV, neighbours, kids. She only has me and her father to speak in Arabic, and she doesn't spend much time with her father. By the time my husband returns from work, my kids are already sleeping. ${ }^{52}$

The struggle to retain Arabic in the home in a context that is so pervasively English is immense. Parents feared the growth of a cultural gulf between themselves and their children brought on by assimilation. Activities like Arabic school on Sundays were cultural initiatives to try to prevent complete assimilation. While this interviewee was seeking integration into Canadian society for her family, she also wanted to hold onto the language, arts, and culture of her homeland. She especially hoped to preserve them for her children.

Interviewees described holding onto their heritage while also embracing new traditions: "You have to meet new people and get involved and share with them their festivities. For example, I'm celebrating Halloween now. I put all the decorations outside, and the pumpkins. It's very nice. My kids really like this holiday and they haven't even seen it yet. I for one don't know anything about it [laughter]. They got bowls, and I'm very happy and pleased." 53

Many stressed the theme of keeping their own cultural practices and values while integrating into Canadian society: 
"You have to mingle with people. They have a lot of nice things [in Canadian culture], and one can learn all the great and good things about a culture and leave the bad things, or the things that don't fit, if we can of course. Even for us older people, we can still integrate. But it's important to have the strength to hold onto your [authentic culture/values]."54

A few respondents reported that they cannot feel themselves Canadians. One participant was asked whether she feels herself as a refugee: "Yes of course. I mean whatever happens, this is not our country. We are taking refuge in it. We are thankful for Canadians for having us. I'm missing something that would make me Canadian."55

Patterns of identity construction were varied, and the experience of newcomers is far from monolithic; however, it appears that all struggle to make sense of their interconnections between Syria, Canada, and the rest of the world, and this is reflected in cultural production in Ontario.

There was evidence for a transnational simultaneous embrace of - and resistance against-Canadian whiteness by many newcomers. ${ }^{56}$ Refugees did not choose to leave home for Canada, and their cultural production in Canada is profoundly affected by this reality. In cultural production the displaced make their agency known. They find Canada a freeing but somewhat problematic environment. One interviewee highlights some of the benefits of cultural expression in Canada from her perspective. As a woman, being in Canada has given her space for unique cultural production that was not available to her while she lived as a displaced Syrian in Saudi Arabia: "There's a lot of respect in Canada.... I've never gotten this much respect, as a woman. Like I'm a feminist. Did I ever dare to even talk about feminism in Saudi Arabia?... But here people respect that I'm a feminist and people like support me. And you know what? We have a voice.... And I've never dreamed about being a model.... And [here] I got to be a model.... Those opportunities and the respect." 57

This participant began professional activity as a hijabi model and fashion-content creator after she arrived in Canada. She took her move to Canada as a launching point for cultural production that centres on her own experiences of hybridity and transnational culture. Syrian ethnically and culturally, she was raised in Saudi Arabia, and now calls Canada home. This has resulted in a unique transnational and hybridized approach to life that is somehow embraced in Canada. She notes that in Canada, friends are always interested in different cultures, and people in general always seem interested in new things. ${ }^{8}$ She has taught friends Syrian dance moves, and shared other elements of her cultural heritage with them: "So, the sharing of cultures, you're mixed up, I love that thing. When I was shooting [modelling], I don't know what I say, I say bismillah, before everything-and when something dropped off I was like, 'Jeez.' And they all looked at me and they were like, 'We love this! You said jeez and bismillah in the same sentence.' I'm like, 'Whatever you guys-we're in Canada!' [laughs] You know, it's a lot of sharing the cultures." 59

Her comment, "Whatever you guys-we're in Canada!" sums up an attitude found amongst many newcomers-that their hybridization in cultural production is positive. Other interviewees also expressed excitement at participating with their families in Canadian holidays, like Halloween and Christmas. ${ }^{60}$ The theme of entering Canadian culture and integrating while holding onto Syrian culture and tradition emerged in numerous narratives from recently displaced Syrians. ${ }^{61}$ Through this hybridization, individuals present culturally non-homogenous artistic production and forge complex and multifaceted identities. ${ }^{62}$

But tensions remain, as many face racism and fear of losing touch with what they left behind. Amir Al-Azraki sums up these feelings completely in an interview he gave to Imprint at the University of Waterloo: "I live between two worlds... I cannot completely integrate into this society, but at the same time I cannot go back and integrate completely in my own culture anymore. I'm like a floating island."63

\section{Conclusion}

The ongoing war in Syria has made it difficult for the millions who have been displaced to go back to their homelands. Newcomer populations have taken on the difficult task of making places they did not choose their new homes. In this process, displaced Arabic populations in the KitchenerWaterloo Region have built community, shown resilience, and pushed back against stereotypes through their theatrical and dance presentations. Refugees have also spearheaded community dance and theatre initiatives to develop belonging and community. Both professional and community arts initiatives showcase how culture and identity are caught up in circulations of culture, and how acculturation, nostalgia, and assimilation are fraught with complexity and resistance. Professional artists and volunteers have reconfigured presentations of Levantine culture to facilitate community healing and uneven processes of acculturation that suit their adaptation needs. The decision of newcomers to navigate acculturation through cultural hybridization in theatre and dance allows them to resist traditional assimilation. Nostalgia and transnational connections in cultural production indicate the development of new internationally interconnected networks of Syrian cultural production and identity.

\section{Acknowledgment}

This article was made possible by NPRP grant NPRP9-225-5024 from the Qatar National Research Fund (a member of 
Qatar Foundation), titled "Transcultural Identities: Solidaristic Action and Contemporary Arab Social Movements." The grant is led by Eid Mohamed and is based at the Doha Institute for Graduate Studies. The findings achieved herein are solely the responsibility of the author(s).

\section{Notes}

1 Statistics Canada, "Results from the 2016 Census: Syrian Refugees Who Resettled in Canada in 2015 and 2016," December 19, 2018, https://www15o.statcan.gc.ca/n1/ pub/75-006-x/2019001/article/oooo1-eng.htm.

2 Jeff Outhit, "Waterloo Region Growing but Not as Fast, Census Shows," Record, February 8, 2017, https://www. therecord.com/news-story/7110570-waterloo-regiongrowing-but-not-as-fast-census-shows/.

3 Statistics Canada, "Focus on Geography Series, 2016 Census," February 8, 2017, https://www12.statcan.gc.ca/censusrecensement/2016/as-sa/fogs-spg/Facts-cma-eng.cfm?LAN $\mathrm{G}=$ Eng \& $\mathrm{GK}=\mathrm{CMA} \& \mathrm{GC}=541 \&$ TOPIC $=7$.

4 Phillip Connor, "Most Displaced Syrians Are in the Middle East, and About a Million Are in Europe," Pew Research Center, January 29, 2018, http://www.pewresearch.org/fact$\operatorname{tank/2018/01/29/where-displaced-syrians-have-resettled/;~}$ Jynnah Radford and Phillip Connor, "Canada Now Leads the World in Refugee Resettlement, Surpassing the U.S.," Pew Research Center (blog), June 19, 2019, https://www .pewresearch.org/fact-tank/2019/o6/19/canada-now-leadsthe-world-in-refugee-resettlement-surpassing-the-u-s/.

5 For the purpose of this article, culture is defined as a shifting set of shared societal expectations that help individuals make meaning out actions, objects, and artistic expressions. This definition of culture is based on the work of Lila AbuLughod, which stresses the importance of non-objectivity, vibrancy, and life in defining culture. Lila Abu-Lughod, "Writing against Culture," in Recapturing Anthropology: Working in the Present, ed. Richard Fox, 137-9 (Santa Fe, NM: School of American Research Press, 1991).

6 Shamrose for Syrian Culture and Levant are two non-profit Syrian cultural organizations that were founded in the wake of the Syrian crisis to support refugee resettlement in Canada through sponsorship support, cultural programs, and community building. The K-W Multicultural Centre's mandate is to foster diversity and inclusion in the region by ensuring all who live in the region can participate fully in community.

7 Katherine Borland, “That's Not What I Said': Interpretative Conflict in Oral Narrative Research," in The Oral History Reader, ed. Robert Perks and Alistair Thompson, 2nd ed. (New York: Routledge, 1998), 310.

8 As the researcher decides on how information is collected, and what information is published, he or she always has power over the narrative constructed. Anna Sheftel and Stacey Zembrzycki, eds., Oral History Off the Record:
Toward an Ethnography of Practice (New York: Palgrave MacMillan, 2013), 5.

9 Sarah Holcombe, "The Arrogance of Ethnography: Managing Anthropological Research Knowledge," Australian Aboriginal Studies 2, no. 2 (November 2010): 25.

10 Shulamit Reinharz, "Neglected Voices and Excessive Demands in Feminist Research," Qualitative Sociology 16, no. 1 (March 1993): 69-76.

11 Sarah Deardorff Miller, Political and Humanitarian Responses to Syrian Displacement (London: Routledge, 2016), vii.

12 Miller, Political and Humanitarian Responses, vii.

13 Miller, Political and Humanitarian Responses, vii.

14 New Arab, "Dozens Killed in Syrian Regime Barrel Bombing of Eastern Ghouta," March 5, 2018, https://www.alaraby .co.uk/english/news/2018/3/5/dozens-killed-in-syrianregime-bombardment-of-eastern-ghouta.

15 Euan McKirdy, "8 Times Russia Blocked a un Resolution on Syria," cNN, April 13, 2017, https://www.cnn.com/ 2017/04/13/middleeast/russia-unsc-syria-resolutions/ index.html.

16 Miller, Political and Humanitarian Responses, viii.

17 Miller, Political and Humanitarian Responses, ii.

18 Petra Molnar, "The Boy on the Beach: The Fragility of Canada's Discourses on the Syrian Refugee 'Crisis," Contention 4, no. 1-2 (June 1, 2016): 72, https://www.berghahnjournals .com/view/journals/contention/4/1-2/conto40106.xml? pdfVersion=true.

19 Molnar, "Boy on the Beach," 70.

20 Anne-Marie McMurdo, "Causes and Consequences of Canada's Resettlement of Syrian Refugees," Forced Migration Review 52 (2016): 82.

21 Miller notes that Justin Trudeau's commitment to refugees was a key factor in his election win. Miller, Political and Humanitarian Responses, 117.

22 Miller, Political and Humanitarian Responses, 117.

23 Pro-Trump racist, xenophobic, anti-immigrant, and antirefugee sentiment certainly still existed/exists in Canada.

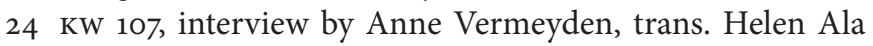
Rashi, November 30, 2017.

25 Immigration Partnership, 2017/2018 Progress Report (Waterloo Region: Immigration Partnership, 2018), 4.

26 Immigration Partnership, 2017/2018 Progress Report, 2.

$27 \mathrm{KW} \mathrm{110}$, interview by Anne Vermeyden, trans. Helen Ala Rashi, December 4, 2017.

$28 \mathrm{KW}$ 102, interview by Anne Vermeyden, trans. Helen Ala Rashi, February 27, 2017.

29 The Orientalist perspectives found in Canada during the twentieth century of an imagined exotic, feminine, sensual East have been used not to facilitate colonial control over areas of the Middle East and North Africa, but instead to justify racial discrimination within Canada itself. Systematic and casual discrimination against peoples from North Africa and the Middle East has been perpetuated by unfair ethnic stereotyping in popular entertainment in 
Canada. Constance Backhouse, Colour-Coded: A Legal History of Racism in Canada, 1900-1950 (Toronto: University of Toronto Press, 1999), 4.

30 The student was suspended for three days, indicating the school recognized the unacceptability of this outburst. However, the fact that he said it in the first place indicates extant attitudes of racism and/or islamophobia in the community. KW 102.

$31 \mathrm{KW} 102$.

32 Reem Hajali, interview by Anne Vermeyden, December 8, 2017.

33 Vappu Tyyskä, Jenna Blower, Samantha DeBoer, Shunya Kawai, and Walcott Ashley, "The Syrian Refugee Crisis in Canadian Media," ed. Shuguang Wang, Ryerson Centre for Immigration and Settlement Working Paper, no. 3 (2017): 15.

34 Tyyskä et al., "Syrian Refugee Crisis in Canadian Media," 6-7.

35 свс Radio, "How Syrian Refugees Arriving in Canada Became 'Extras' in Their Own Stories," February 21, 2016.

36 Amir Al-Azraki, The Mug, University of Waterloo Art Gallery, November 23, 2017.

37 "Arab Culture in Diaspora," November 23, 2017.

38 Faith Rahman, "A Translation of Arabic Language and Diaspora," Imprint, November 30, 2017, http://uwimprint .ca/article/a-translation-of-arabic-language-and-diaspora/.

39 KM 107.

40 свс News, "Syrian Actors Take Centre Stage This Weekend at Registry Theatre," February 16, 2017.

41 James Heaslip, "Kiss Is Wild and Watchable, but Falls Behind on the Syrian Conflict," Globe and Mail, April 2, 2017, https:// www.theglobeandmail.com/arts/theatre-and-performance /theatre-reviews/kiss-is-wild-and-watchable-but-fallsbehind-on-the-syrian-conflict/article34555551/.

42 свс News, "Syrian Actors Take Centre Stage."

43 One interviewee related that she attended the show twice because she was so moved by it. She also encouraged her friends in Canada to attend. KW 112, interview by Anne Vermeyden, trans. Helen Ala Rashi, December 6, 2017.

44 Homsi is known throughout the Arab world for her leadership in experimental and avant-garde theatre. Not only was she Syria's first female professional mime, but she was also a leader in non-verbal theatrical experimentation across the Middle East. Homsi has also written and directed numerous plays and monodramas that have toured globally, and she has achieved theatrical awards at the international level. Martin DeGroot, "Arabic Comedy Celebrates Courage and Strength of Refugees," Record, June 21, 2013, https://www therecord.com/whatson-story/3851265-arabic-comedycelebrates-courage-and-strength-of-refugees/.

45 KM 107.

46 Hajali, interview.

47 ww10o, interview by Anne Vermeyden, trans. Helen Ala Rashi, October 19, 2017.

$48 \mathrm{Rxx}$, interview by Anne Vermeyden, trans. Helen Ala Rashi, December 8, 2017.

49 ww100, interview.

50 ww10o, interview.

51 Lucy Maddox, ed., Locating American Studies: The Evolution of a Discipline (Baltimore, MD: Johns Hopkins University Press, 1998), 344.

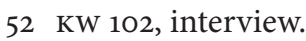

53 KW 102, interview.

54 KW 102, interview.

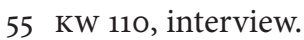

56 Whiteness, socially, culturally, and even geographically constructed, is a dominant norm in Canada. Often newcomers feel intense pressure to fall in line with its social and cultural requirements. For more on this, see Andrew Baldwin, Laura Cameron, and Audrey Kobayashi, Rethinking the Great White North: Race, Nature, and the Historical Geographies of Whiteness in Canada (Vancouver: UBC Press, 2011), 4-5.

57 Hajali, interview.

58 Hajali, interview.

59 Hajali, interview.

$60 \mathrm{KW} \mathrm{102,} \mathrm{interview.}$

61 KW 102, interview; Hajali, interview.

62 This article's use of the term hybridity is derived from the work of Homi K. Bhabha. Homi K. Bhabha, The Location of Culture (New York: Routledge, 1994), 5, 10.

63 Rahman, "Translation of Arabic Language and Diaspora."

Anne Vermeyden is a writing consultant at Conestoga College. She can be reached at avermeyden@conestogac.on.ca.

Eid Mohamed is an assistant professor of Arab-US Cultural Politics at the Doha Institute for Graduate Studies. He can be reached ateid.mohamed@dohainstitute.edu.qa. 